\title{
Interferon Regulatory Factor 6
}

National Cancer Institute

\section{Source}

National Cancer Institute. Interferon Regulatory Factor 6. NCI Thesaurus. Code C75618.

Interferon regulatory factor 6 ( $467 \mathrm{aa}, \sim 53 \mathrm{kDa}$ ) is encoded by the human IRF6 gene.

This protein plays a role in the regulation of transcription. 